\title{
A Sanskrit Text of the Nepalese Buddhist Homa
}

\section{Shinobu YAMAGUCHI}

\section{Homa rituals in Newar Buddhism}

In the Kathmandu Valley, Newar Buddhism, preserves the tradition of Indian Buddhist Tantrism to a great extent. In Newar Buddhism, pūjā (offering worship) and homa (fire offering ritual) are popular. Homa rituals are performed in order to remove obstacles and diseases.

On the second of August, 1994, a homa ritual was performed at the house of a Newar Buddhist priest, Rev. Ratnakajee Vajracharya. In that year, his first and second sons were married. In the Kathmandu Valley, Buddhist priests perform several kinds of homa rituals such as Māṃsāhutihoma and Śirāhutihoma. The homa performed in 1994 was called Sahasrāhutihoma (one thousand offering homa ritual), which is very popular among Newar Buddhists. Sahasrāhutihoma is also performed for other occasions such as the construction of a stūpa or the celebration of someone becoming seventy-seven years old, and so on. The homa that I observed began at 8 o' clock A. M. and continued for three hours. At that time, the priest performed the ritual according to the Sanskrit text named Kalaśärcanahomavidhi.

\section{Kalaśärcanahomavidhi}

There are several Sanskrit manuscripts and a few printed editions of Sahasrāhutihoma. The titles of the text are various:Kalaśārcanahomavidhi, Sahasrāhutihomavidhi, and Yajũavidhāna. The content of each text differs. In most texts, mantras are written in Sanskrit and explanations are written in Newari.

The text Kalaśārcanahomavidhi, which was used in the homa in 1994, was edited by Newar Buddhist priest Rev. Amoghavajra Vajracharya in 1973. It was published in a twenty-page booklet. In the text, mantras and some explanations of the process of rites 
are written in Sanskrit, and the some additional explanations are given in Newari.

The contents of Kalaśärcanahomavidhi are as follows :

1. Preliminary rite : Kalaśārcanapūjā

1. 1 Gurumaṇdalapūjā

1. 2 Trisamādhi

1. 3 Kalaśapūjā

2. Main rite : Homa

2. 1 Purification and lighting of the fireplace (agnisthāpana)

2. 2 Fire offering (āhuti) to the fire god Agni (agnyāhuti)

2. 3 Fire offering to the main deity

2. 4 Bali offering (balipūjā), worship of holy places (pịthādipūjāa) and sacred places located in the eight directions (cākrapūjā)

2. 5 Purification of disciples (śișyādhivāsana)

2. 6 Filling the fireplace with offerings (pūrnāhuti)

2. 7 Offering the remainders of oblations (śeșāhuti)

2. 8 Sending forth the gods (visarjana)

Kalaśärcanahomavidhi is divided into two parts ; that is, a preliminary rite and a main rite. The first part, Kalaśārcanapūjāā, consists of three rites:(1) Gurumanḍalapūjāa (Worship of Gurumaṇ̣ala), (2) Trisamādhi (Three meditations), and (3) Kalaśapūjā (Worship of a jar). Gurumaṇdalapūjā is one of the most fundamental rituals in Newar Buddhism. In Gurumaṇdalapūjā, a priest performing the ritual invites Vajrasattva, who is considered a master (guru) of Newar Buddhist priests, into a circle called "gurumaṇdala" drawn in front of the priest. The priest puts flowers, rice, incense and other materials to the Guruma-ṇdala.

The second part of the prelimainary rite, Trisamādhi, contains three steps of meditation and the worship of Cakrasaṇvaramandala. The third rite, Kalaśapūjā is the worship of the deity invited into a jar put in the ritual place. In the main rite, Homa, oblations are offered to the deity. Therefore, Kakaśapūjā is indispensable for Sahasrāhutihoma (Locke, 1980, p.106).

After the preliminary rite, the main rite, Homa begins. In Newar Buddhism, the Homa is often called "homapujā." That is to say, Homa is considered a kind of pūjā. In the first part of the main rite, the yajamāna (sacrificer) or the patron puts the kuśa grass in the form of swastika inside the fireplace for purification. Then the priest salutes the guru Va- 
jrasattva reciting “om vajrasattva āh." Then, the priest recites a prayer to remove all obstacles from the yajamāna.

After the purification, the priest puts fuel sticks called somsi (Nw.): in a small clay vessel (Nw. sali) before him. Next the fuel sticks are lit. The fire on the sticks is called bhūtāgni. Then the priest fires the sticks piled up inside the fireplace, reciting a prayer asking for the completion of the homa in order to fulfil yajamāna's desires.

Then, the priest meditates upon Samayāgni (the fire god of promise), who is yellowcolored with one face and four arms. He has a staff (danda) and a water jar (kamandalu) in his two left hands, and a rosary in one right hand. His other right hand shows a boongiving gesture (varadamudrā). He wears a yellow garment and a crown decorated with the image of Vajrasattva.

Having meditated, the priest invites Samayāgni to the fireplace. Then he offers water, and flowers, etc., to the deity. Later, he draws Samayägni into the fire. Having done this, the priest pours clarified butter (ghrta) with a ladle into the fire one hundred eight times. The action is called agnyāhuti.

As soon as the butter is offered, eighteen kinds of fuel sticks (Nw. homvīi), grains, beans, and milk etc. are offered to Samayāgni. Then the priest meditates upon Jñānāgni (the fire god of knowledge). Later, the priest meditates that Samayāgni and Jñānāgni should be united as milk is mingled with water (kșiraniram iva). Then, the clarified butter is offered to the unity of the Samayāgni and Jñānāgni. Meditations of Samayāgni and Jñānāgni are often referred to in Indian Buddhist Tantras, such as Samvarodayatantra (Tsuda, 1974, p.139).

Next, the third part of the main rite, the fire offering to the main deity of the homa, starts. In the homa I observed in 1994, the image of Akșobhya Buddha was put as the main deity of the ritual. The third part is divided into three steps : (1) Worship of the main deity (devapūjā), (2) Offering clarified butter and grains to the main deity (devatāhuti), and (3) One thousand offerings (sahasrāhuti).

In (1), the yajamāna offers water for sipping and washing feet, five kinds of nectar (pa ñcāmrta), and a mirror, etc., to the main deity. In (2), the priest pours water from a conch shell and five kinds of nectar into the image in order to bathe the main deity. Next, the priest offers fuel sticks, grains, clarified butter to the main god. This rite is called devatāhuti. 
In (3), Sahasrāhuti, the declaration of the ritual (samkalpa) and the offering to the fire are done. First, the priest wears a red cloth (Nw. kasāygā, Skt. kașāyavastra). Then he declares the date, the place and the purpose of the homa to be performed. The declaration is called kasāygā-saṃkalpa. Next, the priest offers a mixture of rice, clarified butter, milk and black sesame into the fire one thousand times. The action is called sahasrāhuti, which is the climax of the Sahasrāhutihoma.

As soon as Sahasrāhuti has been performed, the fourth part of the homa, the Bali offering (balipūjā) starts. Bali is offered to the guardian deities such as Indra, Yama and Varuna etc., goddesses yoginīs and ḍakinīs, spirits, and so on, who, while not called directly, accompany the invited deities. In order to pacify them, Bali is offered. In Sahasrāhutihoma, the Bali obaltion usually contains cooked rice, beans, and flowers.

In the Bali offering, the priest salutes the guardian deities of ten directions. At that time, the yajamāna pours water from the conch shell into the Bali oblation. Next, the yajamāna pours rice beer into the Bali oblation in order to again pacify the goddesses yoginīs and dākinis, while the priest is reciting the mantras.

Then, the worship of the holy places (pitha) and the sacred places of the eight directions begins. The text refers to ten kinds of holy places, such as pițha, upapitha, kșetra, upakșetra, chandoha, and upachandoha. Those names often appear in the Buddhist tantras such as Samvvarodayatantra.

Most of Newar Buddhist rituals end with the Bali offerings. In the Sahasrāhutihoma, however, some rites follow the Bali offering such as the purification of disciples (śisyādhivāsana). There the text says briefly, "Śișyādhivāsana should be done by the members of the yajamāna holding five-colored strings, if it is necessary." In the home in 1994, the family of the yajamāna performed Śiṣyādhivāsana, while the priest was reciting mantras. However, no mantras are mentioned in the text. Rev. Gautam Ratna Vajracharya, who was the yajamāna of the homa ritual, says that Śsisyādhivāsana is performed to purify the individual soul (ātman) of each member of the yajamāna's family.

Then, the sixth part of the homa, namely, filling the fireplace with offerings (pūrnāhuti), starts. The priest offers water from the conch shell for sipping and washing the feet of the main deity. Next, reciting mantras, he throws fifteen kinds of offerings into the fire. The offering materials are a bel fruit, a sacred thread (yajñopavita), flowers, incense, coconut, sugarcane, sweets, and thirty-two kinds of medicainal plants and so on. 
According to the late Rev. Ratnakajee Vajracharya, who was the priest of the homa I observed, the medicinal plants are offered in order to take away diseases from the yajamāna's family members. Offering various kinds of obaltions, the priest recites a prayer, asking that the homa should be completed by performing Pūrṇāhuti. The Pūrṇāhuti seems to be a confirmation of the Sahasrāhutihoma.

Then, the seventh part, the Śșāhuti or offering the remainder of the oblations, begins. It is the concluding rite of the homa. Here in the Seșāhuti, the priest meditates upon the maṇuala of Agni who was meditated in the Agnyāhuti. He draws the maṇdala into his body, and meditates upon Agni again. Next, he offers the remainder of calrified butter and grains to Agni, reciting a prayer indicating that all the creatures should be happy. The text ends with sending forth all gods and spirits, etc. who came to the ritual place (visarjana).

\section{Conclusion}

The Kalaśärcanahomavidhi explains the process of the Sahasrāhutihoma, which is one of the most popular homa rituals in Newar Buddhism. The text consists of two parts, namely, the Kalaśārcanapūjā and the Homa. The former includes three kinds of pūjās; the latter, the Homa and some additional pūjās. Sahasrāhutihoma, mentioned in the Kalaśārcanahomavidhi, is a complex combination of two different rites : the homa and the pūjā.

In the main Homa, there are four kinds of fire offerings : Agnyāhuti, Devatāhuti, Pūrṇāhuti, and Śeșāhuti. In the first Agnyāhuti and the last Śeșāhuti, clarified butter, grains, etc., are offered to the fire god Agni. In the second Devatāhuti and the third Pūrnāhuti, however, the oblations are offered to the main deity. The homa in Newar Bddhism has preserved the structure of ancient Indian Śrauta homa to a considerable degree.

The priest meditates upon Samayāgni and Jñānāgni and unites them in Agnyāhuti. Then in Śeșāhuti, the priest draws the manḍala of Agni into his own body. The process is a kind of yoga, which is popular in the Buddhist Tantrism. It is obvious that the concepts of Samayāgni and Jñānāgni are based upon the two famous concepts of Buddhist Tantric sādhana (realization) : Samaya-sattva and Jñāna-sattva.

\section{References :}

Locke, J. (1980). Karunamaya. Kathmandu : Sahayogi Prakashan.

Tsuda, S. (1974). The Samvarodaya-tantra : Selected Chapters. Tokyo : Hokuseido Press. 
(文部省科学研究費補助金による研究成果の一部)

$<$ Key Words $>$ Newar Buddhism, homa, Buddhist Tantrism

(Associate Professor, Chukyo Women's University, Ph. D. )

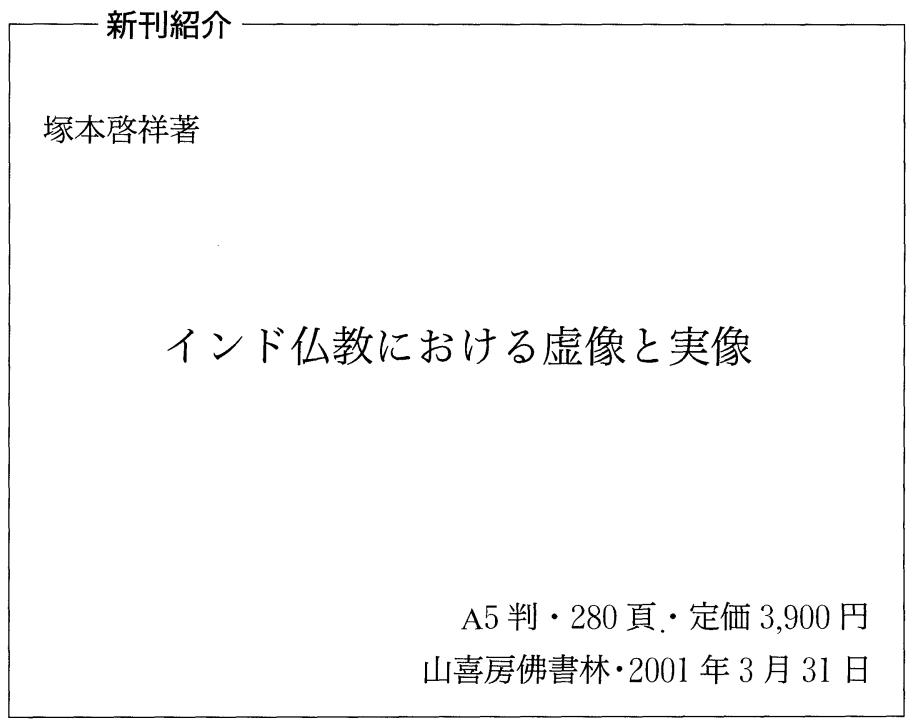

